\title{
Production and Decomposition of Cover Crop Residues and Associations With Soil Organic Fractions
}

\author{
José Carlos Mazetto Júnior ${ }^{1}$, José Luiz Rodrigues Torres ${ }^{2}$, Danyllo Denner de Almeida Costa ${ }^{1}$, \\ Venâncio Rodrigues e Silva ${ }^{1}$, Zigomar Menezes de Souza ${ }^{3} \&$ Ernane Miranda Lemes ${ }^{1}$ \\ ${ }^{1}$ Agrarian Sciences Institute, Federal University of Uberlândia, Uberlândia, Brazil \\ ${ }^{2}$ Federal Institute of Triângulo Mineiro, Uberaba, Brazil \\ ${ }^{3}$ Agrarian Engineering School, Campinas State University, Campinas, Brazil \\ Correspondence: Ernane Miranda Lemes, Agrarian Sciences Institute, Federal University of Uberlândia, Campus \\ Gloria, BR 050, km 78, Uberlândia, Brazil. Tel: 55-342-225-8444 ext. 230. E-mail: ernanefito@gmail.com
}

Received: January 28, 2019

Accepted: February 27, 2019 Online Published: April 15, 2019

doi:10.5539/jas.v11n5p58

URL: https://doi.org/10.5539/jas.v11n5p58

\begin{abstract}
The decomposition of plant residues, the changes in the total organic carbon (TOC) and the fractions of soil organic matter (SOM) occur differently in irrigated areas. The objective of this study was to quantify the biomass production, the decomposition of cover crops residues and relate them with the changes $\mathrm{n}$ the content and fractions of SOM in an irrigated area of vegetable crops. Six types of cover crop treatments were evaluated: brachiaria (B); sunn hemp (S); millet (M); B + S; B + M; S + M, plus an additional treatment (native area), with 4 repetitions. The production of fresh (FB) and dry biomass (DB), the rate of plant residue decomposition, TOC, SOM fractions and the coefficient of SOM (QSOM) were quantified. It was observed that the greatest and the lowest volume of crop residues were from the B and S cover crop, respectively. The cover crops in monoculture presented great decomposition rates and short half-life when compared to mixtures of cover crop. The TOC and QSOM were great in the 0 to $0.05 \mathrm{~m}$ soil layer, and in the $\mathrm{M}+\mathrm{S}$ cover crop mixture, when compared to the 0.05 to $0.1 \mathrm{~m}$ soil layer and to other cover crops. Among the SOM fractions, the humin predominated in the most superficial soil layer ( 0 to $0.05 \mathrm{~m}$ ).
\end{abstract}

Keywords: no soil tillage, dry winter crops, litter decomposition, soil organic carbon

\section{Introduction}

Along with the technological innovations adopted for agricultural production in the Brazilian Cerrado (Savannah like biome), the no-tillage system (NTS) is one of the most expressive and the one that has brought many changes to the previous system of crop production.

The NTS has grown exponentially up to $30 \%$ a year, reaching a total area cultivated of 32 million hectares in the season 2014/2015 (Motter \& Goelzer, 2015). This expansion has always been associated with the development of new technologies for crop management, like crop rotation and the selection of plants adapted to the edaphoclimatic conditions of the Cerrado region.

Among the plant species used as cover crops for NTS in Cerrado, brachiaria (signalgrass), millet and sunn hemp are well adapted to its edaphoclimatic conditions and produce great amounts of biomass (Torres et al., 2017; Pacheco et al., 2017; Ceballos et al., 2018). These plants in summer produce about 6 to $13 \mathrm{Mg} \mathrm{ha}^{-1}, 7$ to $12 \mathrm{Mg}$ $\mathrm{ha}^{-1}$ and 4 to $9 \mathrm{Mg} \mathrm{ha}^{-1}$, while in winter these values reduce to 2 to $3 \mathrm{Mg} \mathrm{ha}^{-1}, 2$ to $4 \mathrm{Mg} \mathrm{ha}^{-1}$ and 3 to $5 \mathrm{Mg} \mathrm{ha}^{-1}$, respectively (Assis et al., 2016). The cultivation of brachiaria (signalgrass), millet and sunn hemp as cover crops also provide greater soil coverage and nutrient cycling than other plants used at this biome (Torres et al., 2008; Carvalho et al., 2011; Assis et al., 2016; Pacheco et al., 2018).

However, the maintenance, decomposition and nutrient cycling of crop residues occur differently in natural conditions, and faster in irrigated areas (Torres et al., 2013; Branco et al., 2017). This is due to changes in temperature and soil moisture that directly influence the rate of organic matter decomposition (Pacheco et al., 2013; Collier et al., 2018). 
The continuous deposition of plant residues that occurs in the NTS increases soil organic matter (SOM), total organic carbon (TOC) and nutrients in soil, especially, when associated with an efficient system of crop rotation (Pereira et al., 2010). Loss et al. (2013) demonstrated that TOC can be used as one of the main indicators of soil quality, since it has a direct influence on soil physical, chemical and biological attributes. According to Bernoux et al. (2006), 58\% of the SOM consists of TOC and the carbon accumulation rate varies from 0.4 to $1.7 \mathrm{Mg} \mathrm{ha}^{-1}$ year ${ }^{-1}$, with an average accumulation of $0.65 \mathrm{Mg} \mathrm{ha}^{-1}$ year $^{-1}$ at the 0 to $0.4 \mathrm{~m}$ soil layer.

Crop rotation associated with a rational use of cover crops can reduce losses of TOC by the continuous maintenance of plant residues on soil surface and the physical protection of SOM within the soil aggregates (Zotarelli et al., 2012). Lal (2006) verified that reduced tillage and crop rotation alternating Fabaceae and Poaceae plants increase soil biodiversity due to the addition a variety of organic materials making the environment able to absorb and accumulate more carbon.

Some fractions of the SOM can express the changes in soil quality as a function of the management adopted. Carbon from humic fractions of the SOM (oxidizable carbon) (Loss et al., 2013), carbon from granulometric fractions of the SOM (Rossi et al., 2011) and carbon from the light organic matter in water (Guareschi et al., 2012) can be used as indicators for accessing the changes due to land uses. To illustrate the magnitude of the influence of these labeled organic fractions in soil, the soil cation exchange capacity (CEC) of organic origin in the most superficial soil layers is highly improved by increments in humic acids (Benites et al., 2003).

Rossi et al. (2011) found that the increase of the of humic fraction in soybean areas grown under NTS and on residues of brachiaria and sorghum, demonstrated that the chemical fractions of SOM is predominated by the humin fraction, in relation to the humic acid and fulvic acid, the cultivation of soybean on brachiaria residues increases the accumulation of carbon in the humin fraction, and the TOC content differs between the different systems used at $0-0.05,0.05-0.1$, and $0.1-0.2 \mathrm{~m}$ soil depths. The evaluation of the TOC in the soil layer of $0-0.3$ $\mathrm{m}$, verified higher stocks in areas with 8 and 12 years of NTS in the Cerrado biome, without significant differences between these areas (Siqueira Neto et al., 2009), indicating the importance of such system to the organic carbon in soil.

The majority of the studies evaluating the decomposition of plant residues and the changes that occur in the stock of TOC and in the fractions of soil organic matter have been done in areas under natural conditions, however, in irrigated areas it is necessary to better assess the information missing for this condition. In this context, the objective of this study was to quantify the biomass production, residues decomposition and relate them with the changes caused in the fractions of soil organic matter in an NTS area under irrigated cultivation of vegetables in the Cerrado edaphoclimatic conditions.

\section{Method}

\subsection{Description of the Experimental Areas}

The study was conducted in an experimental area of the Instituto Federal do Triângulo Mineiro (IFTM), campus Uberaba, MG, Brazil, located at the coordinates 19 $39^{\prime} 43.4^{\prime \prime} \mathrm{S}$ latitude, $47^{\circ} 57^{\prime} 57^{\prime \prime} \mathrm{W}$ longitude, at an altitude of $795 \mathrm{~m}$ above sea level, between September 2016 to April 2017.

The climate of the region is classified as Aw tropical hot according to Koppen (1934), with a cold and dry winter. The yearly historical average of precipitation and temperature in the region are $1600 \mathrm{~mm}$ and $22.6{ }^{\circ} \mathrm{C}$, respectively (INMet, 2018).

The soil of the area was classified as a dystrophic red Oxisol medium texture (Santos et al., 2013), presenting in the topsoil $(0-0.2 \mathrm{~m})$ : water $\mathrm{pH}=5.7 ; 31.67 \mathrm{mg} \mathrm{dm}$ of $\mathrm{P} ; 0.25 \mathrm{cmol}_{\mathrm{c}} \mathrm{dm}^{-3}$ of $\mathrm{K} ; 1.57 \mathrm{cmol}_{\mathrm{c}} \mathrm{dm}^{-3}$ of $\mathrm{Ca} ; 0.37$ $\mathrm{cmol}_{\mathrm{c}} \mathrm{dm}^{-3}$ of $\mathrm{Mg}$ and $3 \mathrm{cmol}_{\mathrm{c}} \mathrm{dm}^{-3}$ of $\mathrm{H}+\mathrm{Al}$ (Teixeira et al., 2017). In the last four years, the area was cultivated sequentially with cauliflower, broccoli and cabbage in NTS, over the residues of brachiaria, sunn hemp and millet, and irrigated via conventional sprinkler.

\subsection{Experimental Design}

The experimental design was in randomized blocks subdivided in plots, with six types of cover crops or combinations: (B) Brachiaria (Urochloa brizantha cv marandu), (S) Sunn hemp (Crotalaria juncea L.), (M) Pearl millet (Pennisetum glaucum L.-ADR500), B $+\mathrm{S}, \mathrm{B}+\mathrm{M}, \mathrm{M}+\mathrm{S}$, plus an additional treatment (native area-forest), with four repetitions. Each plot had $60 \mathrm{~m}^{2}(10 \mathrm{~m} \times 6 \mathrm{~m})$.

On September 2016 the cover crops were mechanically sown at the rate of 50, 50 and 25 seeds per square meter of brachiaria, millet and sunn hemp, respectively, spaced $0.5 \mathrm{~m}$ between sowing lines. When cover crops were 
mixed $50 \%$ of the seed rate recommendation for each species was used. No fertilizers were applied prior to or during the cover crop cycle.

The cover crops were cultivated from September to November of 2016, at the beginning of the rainy period, and when $50 \%$ of these plants have reached the maximum flowering plant samples were taken in a $2 \mathrm{~m}^{2}$ representative area per plot to evaluate fresh biomass (FB) and dry biomass (DB). The DB was obtained after fresh samples were dried in an oven at $65^{\circ} \mathrm{C}$ for 72 hours. Both mass results were expressed in $\mathrm{kg} \mathrm{ha}^{-1}$.

After sampling, the cover crops were desiccated with glyphosate $\left(792.5 \mathrm{~g} \mathrm{~kg}^{-1}\right.$ active ingredient), and salt of dimethylamine dichlorophenoxyacetic acid $\left(840 \mathrm{~g} \mathrm{~L}^{-1}\right.$ active ingredient), at doses of $2 \mathrm{~kg} \mathrm{ha}^{-1}$ and $2 \mathrm{~L} \mathrm{ha}^{-1}$ of the commercial product, respectively.

\subsection{Evaluations}

The plant residues decomposition was monitored during the period from November 2016 to April 2017. To evaluate the rate of plant residue decomposition it was used the method of decomposing litter bags (plastic bags of $0.2 \times 0.2 \mathrm{~m}$ with $2 \mathrm{~mm}$ mesh), as used by Torres et al. (2013), Assis et al. (2016) and Pacheco et al. (2017). Soon after the dissection of the cover crops, 24 bags were distributed on the soil surface in each plot, and four bags were collected per plot at each sampling time, which occurred at 15, 30, 60, 90, 120, and 150 days after the distribution of the litter bags. In each sampling time the plant residues in each bag were manually collected, dried in a forced air circulation oven at $65^{\circ} \mathrm{C}$ until constant weight to determine the dry biomass of the residues left.

To describe the decomposition of the plant residues it was applied the exponential mathematical model described by Thomas and Asakawa (1993):

$$
X=X_{o} e^{-k t}
$$

where, $X$ is the quantity of dry biomass remaining after a period of time " $t$ " (days); Xo is the initial amount of dry biomass, and " $k$ " is the constant of the residue decomposition. The $\mathrm{k}$ value was calculated as the half-life time $\left(\mathrm{T}^{1 / 2}\right)$ of the plant residue, using the formula proposed by Paul and Clark (1996), which expresses the period of time required for half of the plant residues to decompose:

$$
T^{1 / 2}=0.693 / k
$$

Three soil samples were collected in all plots at 0 to 0.05 and 0.05 to $0.10 \mathrm{~m}$ soil depth. After the collection, samples were air dried for $72 \mathrm{~h}$, and sieved ( $2 \mathrm{~mm}$ mesh) to obtain air-dried fine soil.

The levels of total organic carbon (TOC) were quantified according to Yeomans and Bremner (1988). From the calculated values of TOC, the amount of soil organic matter (QSOM) was estimated with the methodology proposed by the IPCC (2003), using the equation:

$$
Q S O M=S D \times h \times S O M \times 10
$$

where, $\mathrm{QSOM}=$ quantity of soil organic matter $\left(\mathrm{Mg} \mathrm{ha}^{-1}\right) ; \mathrm{SD}=$ soil density $\left(\mathrm{g} \mathrm{cm}^{-3}\right) ; \mathrm{h}=$ thickness of the soil layer $(\mathrm{cm})$; and, $\mathrm{SOM}=$ content of soil organic matter $\left(\mathrm{dag} \mathrm{kg}^{-1}\right)$.

The humic substances were separated in three fractions: fulvic acid (FA), humic acids (HA) and humin (HUM), using the technique of differential solubility established by the International Society of Humic Substances according to the technique adapted by Benites et al. (2003).

\subsection{Statistical Analysis}

The results of this study were analyzed for normality of residues and homogeneity of variances (presumptions of the analysis of variance) by the Shapiro-Wilk and Levene tests, respectively. After attendance of these presumptions, the data were subjected to the analysis of variance ( $F$ test). Significative results of the $F$ test were then compared by the Scott-Knott test of averages $(\mathrm{p}<0.05)$. These analyses were done with the software $\mathrm{R}$ Core Team. The mathematical equations and regression curves of plant residues decomposition were compiled using the SigmaPlot (v. 10) software.

\section{Results}

\subsection{Biomass Production by the Cover Crops}

The production of fresh biomass observed indicated that $\mathrm{B}+\mathrm{S}$ produced greater biomass than other coverages, yielding $34.48 \mathrm{Mg} \mathrm{ha}^{-1}$, while sunn hemp (16.63 $\left.\mathrm{Mg} \mathrm{ha}^{-1}\right)$ in monoculture and $\mathrm{B}+\mathrm{M}\left(18.20 \mathrm{Mg} \mathrm{ha}^{-1}\right)$, presented the lowest amounts observed (Table 1). Regarding DB, the values were inverted and B (11.90 Mg ha $\left.{ }^{-1}\right)$ presented 
superior results when compared to other cover crops, accumulating $51 \%$ of the FB as DB, while $\mathrm{M}, \mathrm{S}, \mathrm{M}+\mathrm{S}, \mathrm{B}$ $+\mathrm{S}$, and $\mathrm{B}+\mathrm{M}$ accumulated only $32,30,29,21$, and $38 \%$, respectively.

Table 1. Production of fresh (FB) and dry biomass (DB) from different cover crops cultivated in Uberaba, MG, in the agricultural year of $2016 / 17$

\begin{tabular}{llc}
\hline Cover crops & FB & DB \\
\hline & $-1.90 \mathrm{a}$ \\
Brachiaria (B) & $23.35 \mathrm{~b}$ & $8.30 \mathrm{~b}$ \\
Millet (M) & $25.90 \mathrm{~b}$ & $5.00 \mathrm{c}$ \\
Sunn hemp (S) & $16.63 \mathrm{c}$ & $6.93 \mathrm{~b}$ \\
$\mathrm{M}+\mathrm{S}$ & $23.87 \mathrm{~b}$ & $7.24 \mathrm{~b}$ \\
$\mathrm{~B}+\mathrm{S}$ & $34.48 \mathrm{a}$ & $6.92 \mathrm{~b}$ \\
B + M & $18.20 \mathrm{c}$ & $30.41^{*}$ \\
Native area & $40.81^{*}$ & 9.43 \\
\hline CV $(\%)$ & 7.25 &
\end{tabular}

Note. $*$ differ from other treatments $(\mathrm{p}<0.05)$. Averages followed by the same letter in column do not differ by the Scott-Knott test $(\mathrm{p}<0.05)$.

\subsection{Decomposition rate and Remaining Biomass}

Through the decomposition constant $(\mathrm{k})$ of the regression curves it is possible to estimate the time of half-life ( $\mathrm{T}^{1 / 2}$ life) of the residues of these cover crop plants, which proves that the decomposition is accelerated in plants in monoculture, because half of the residues of brachiaria, pearl millet and sunn hemp decomposed at 25.5, 28.3 and 23.3 days, respectively; however, when cover crops are mixed, the decomposition period increases, varying between 28.6 and 38.9 days (Table 2), which shows that these rates can change when cover crops are mixed, altering the cycling and release of nutrients for subsequent crops.

Table 2. Decomposition constant $(\mathrm{k})$ and half-life time $\left(\mathrm{T}^{1} / 2\right.$ life) of the remaining biomass from different cover crops in an irrigated area under no-tillage cultivation

\begin{tabular}{|c|c|c|c|c|}
\hline \multirow{3}{*}{ Cover crop } & \multicolumn{4}{|c|}{ Biomass } \\
\hline & \multirow{2}{*}{ Total } & \multicolumn{3}{|c|}{ Remaining } \\
\hline & & $\mathrm{k}$ & $\mathrm{T}^{1 / 2}$ live & $r^{2}$ \\
\hline & $\mathrm{Mg} \mathrm{ha}^{-1}$ & $\mathrm{~g} \mathrm{~g}^{-1}$ & days & - \\
\hline Brachiaria (B) & $11.9 \mathrm{a}$ & 0.0272 & $25.5 \mathrm{c}$ & $0.99^{\text {ns }}$ \\
\hline Millet (M) & $8.3 \mathrm{~b}$ & 0.0245 & $28.3 \mathrm{~b}$ & 0.99 \\
\hline Sunn hemp (S) & $5.0 \mathrm{c}$ & 0.0297 & $23.3 \mathrm{~d}$ & 0.99 \\
\hline $\mathrm{M}+\mathrm{S}$ & $6.9 \mathrm{~b}$ & 0.0242 & $28.6 \mathrm{~b}$ & 0.99 \\
\hline$B+S$ & $7.2 \mathrm{~b}$ & 0.0228 & $30.4 \mathrm{~b}$ & 0.99 \\
\hline $\mathrm{B}+\mathrm{M}$ & $6.9 \mathrm{~b}$ & 0.0178 & 38.9 a & 0.99 \\
\hline Native area & $30.41 *$ & - & $4.21 *$ & - \\
\hline CV $(\%)$ & 9.43 & - & 5.62 & - \\
\hline
\end{tabular}

Note. ${ }^{*}=$ differ from other treatments $(\mathrm{p}<0.05) . \mathrm{ns}$ : non significative $(\mathrm{p}>0.05) . \mathrm{r}^{2}=$ coefficient of determination. Averages followed by the same letter in column do not differ by the Scott-Knott test $(\mathrm{p}<0.05)$.

Additionally, the decomposition of the cover crop residues is accelerated in irrigated areas due to low-temperature variation and great humidity conditions that occur in these areas, improving the action of the soil microorganisms which improves the decomposition rates when compared to natural conditions (no artificial irrigation).

\subsection{Estimate of Total Organic Carbon and the Amount of Soil Organic Matter}

Analyzing the content of TOC it was observed that there were significant differences only in the most superficial soil layer $(0-0.05 \mathrm{~m})$, with values significantly higher in the mixtures $\mathrm{M}+\mathrm{S}\left(1.94 \mathrm{dag} \mathrm{kg}^{-1}\right)$ and $\mathrm{B}+\mathrm{S}(1.79 \mathrm{dag}$ $\mathrm{kg}^{-1}$ ), when compared to the other treatments, which were statistically equal to the observed value of the native 
forest $\left(1.8 \mathrm{dag} \mathrm{kg}^{-1}\right)$. At the soil layer of 0.05 to $0.10 \mathrm{~m}$, there was no difference between treatments and all presented low values when compared to the native forest $\left(1.64 \mathrm{dag} \mathrm{kg}^{-1}\right)$ (Figure 1).

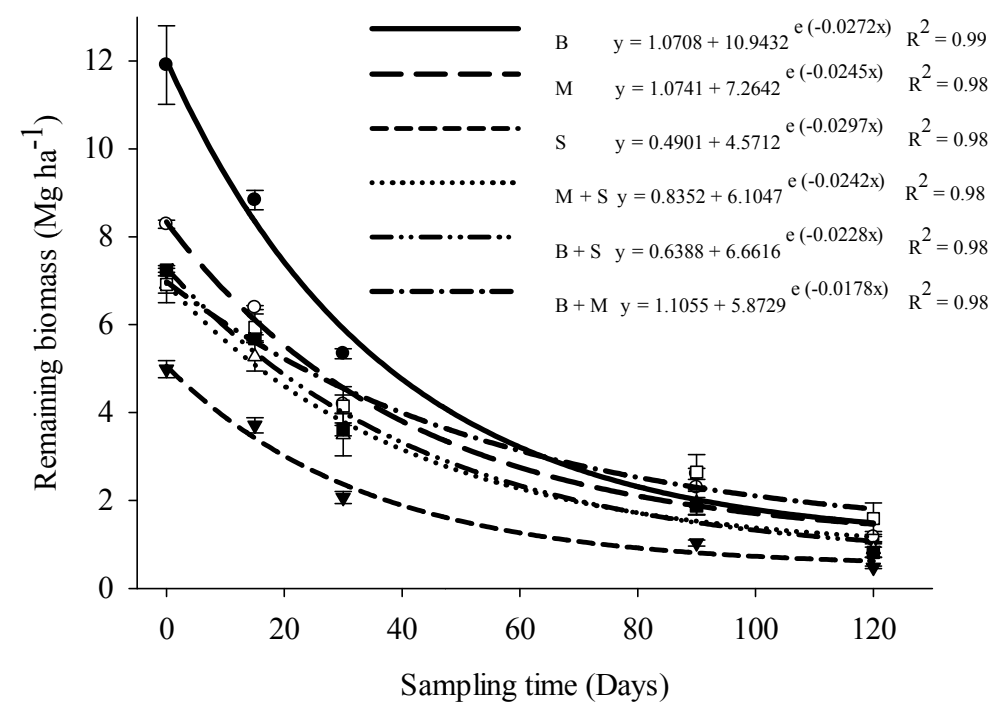

Figure 1. Remaining dry biomass from different cover crops, in area under no-till vegetable cultivation.

B: Brachiaria, S: Sunn hemp, M: Millet

The TOC of the plants individually showed significantly higher values $(\mathrm{p}<0.05)$ for all cover crops in the most superficial layer ( 0 to $0.05 \mathrm{~m}$ ), when compared to the 0.05 to $0.1 \mathrm{~m}$ soil layer (Figure 2). This is common to occur in areas under NTS, because the contents of organic matter are concentrated mostly in the superficial soil layers.

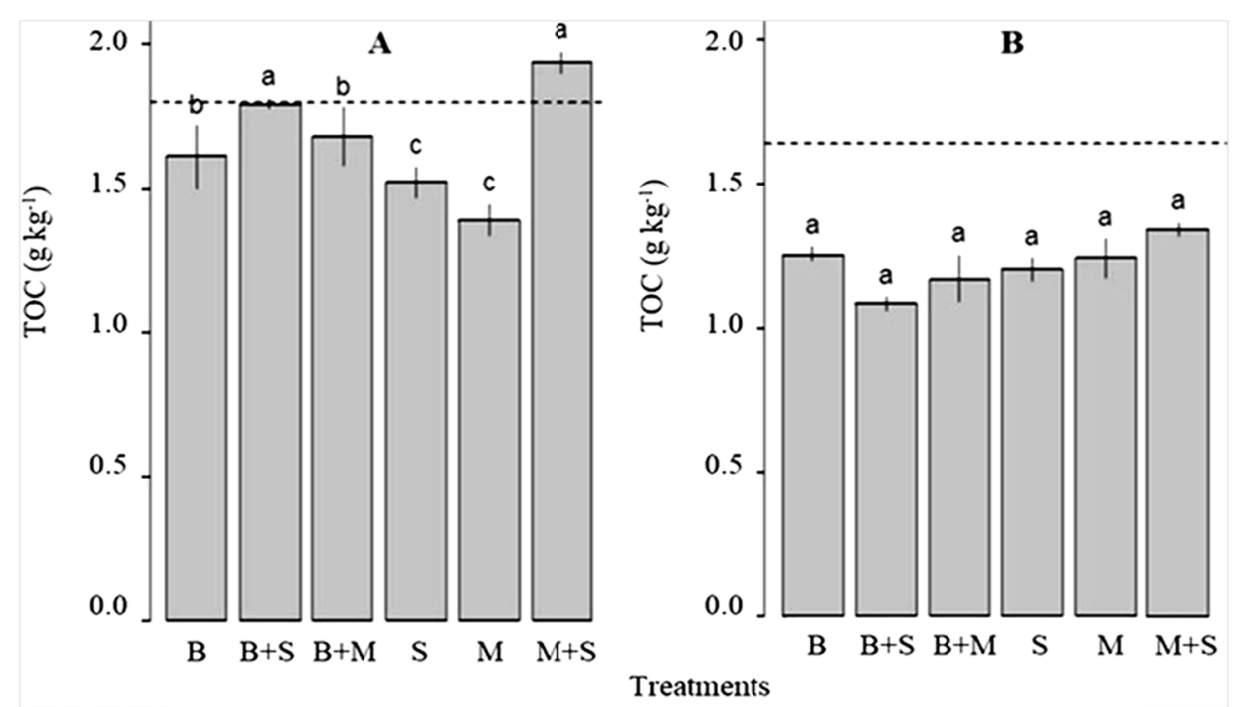

Figure 2. Total organic carbon (TOC) under different cover crops and their mixtures, at 0 to 0.05 (A) and 0.05 to $0.1 \mathrm{~m}$ (B) soil depth, in comparison to the native area (dashed line). B: Brachiaria, C: Sunn hemp, M: Millet

Regarding the coefficient of soil organic matter, the values are significantly higher in the most superficial layer and in areas with mixtures $(\mathrm{p}<0.05)$, with an emphasis on $\mathrm{M}+\mathrm{S}\left(34.22 \mathrm{Mg} \mathrm{ha}^{-1}\right), \mathrm{B}+\mathrm{S}\left(30.87 \mathrm{Mg} \mathrm{ha}^{-1}\right)$ and B $+\mathrm{M}\left(28.07 \mathrm{Mg} \mathrm{ha}^{-1}\right)$, when compared to the native area $\left(22.65 \mathrm{Mg} \mathrm{ha}^{-1}\right)$ (Figure 3). These results can be explained by the higher biomass production of the cover crop mixtures and by the low decomposition rate of the plant residues due to lower carbon/nitrogen $(\mathrm{C} / \mathrm{N})$ ratio, increasing the half-life of the residues and slowly incorporating the organic carbon in the superficial soil layer (Loss et al., 2013). 
B
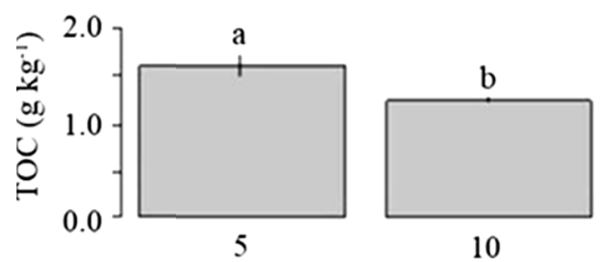

S
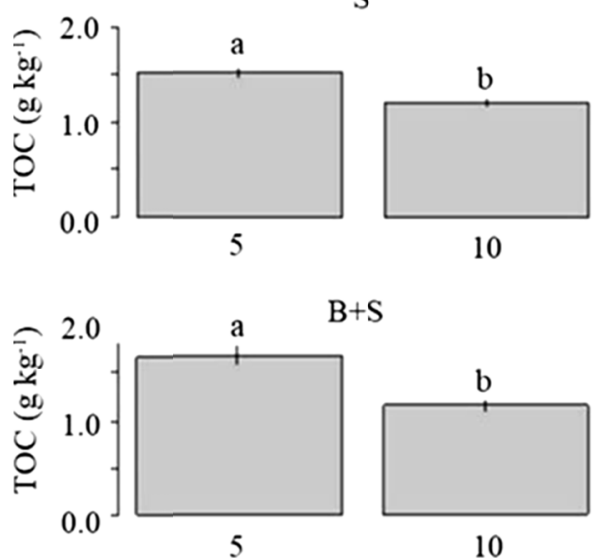

$\mathrm{B}+\mathrm{S}$



10

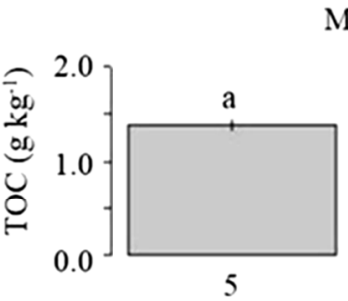

M
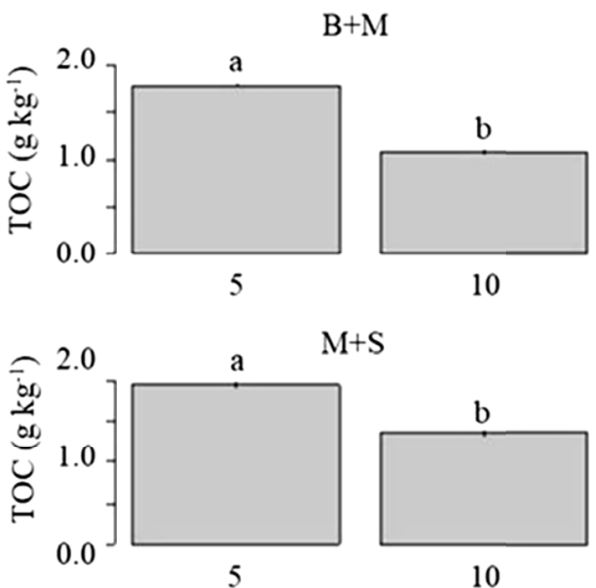

$\mathrm{M}+\mathrm{S}$

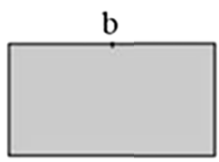

10

Soil depths (cm)

Figure 3. Total organic carbon (TOC) between depths of 0 to 0.05 (A) and 0.05 to $0.1 \mathrm{~m}(\mathrm{~B})$ from the cover crops evaluated. B: Brachiaria, C: Sunn hemp, M: Millet

\subsection{Soil Organic Matter Fractioning}

Analyzing the fractions of organic matter (HA, FA and HUM), it was observed that the values were always higher $(\mathrm{p}<0.05)$ in the most superficial soil layer $(0-0.05 \mathrm{~m})$, what was expected, since most of the plant residues are deposited on the soil surface; this condition, added to the root system in decomposition, demonstrate the great input of organic matter derived from the entire process that is deposited in this soil layer (Figure 4).

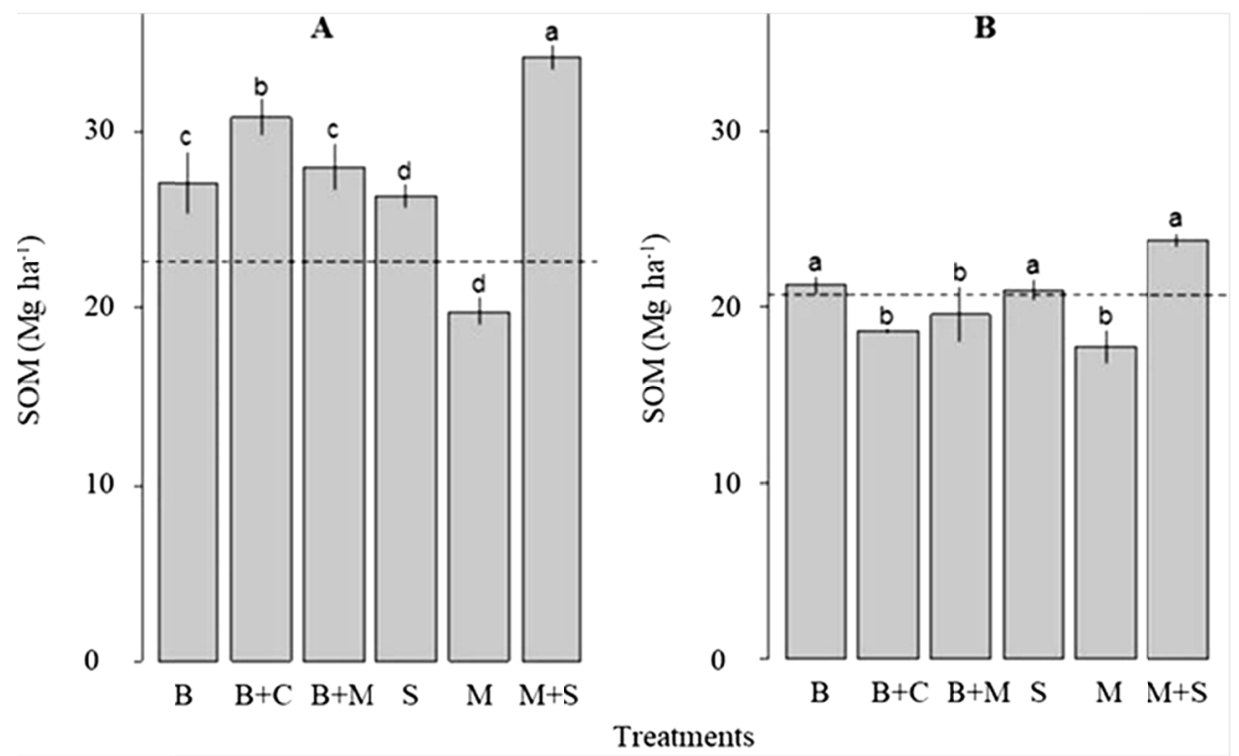

Figure 4. Amount of organic matter under different cover crops at 0 to 0.05 (A) and 0.05 to $0.10 \mathrm{~m}$ (B) soil depths, in comparison to the native area (dashed line). B- Brachiaria, S- Sunn hemp, M- Millet 
Regarding the contents of HA, FA and HUM, there was no interaction between the treatments involving the cover crop and these fractions of organic matter; however, it was possible to verify that among the organic fractions there is a predominance of HUM in relation to FA and HA in the 0 to $0.1 \mathrm{~m}$ soil layer (Figure 5), which presented 9.96, 2.04 and $1.33 \mathrm{~g} \mathrm{~kg}^{-1}$, respectively. This great amount of humin occurs due to its great stability when compared to HA and FA, which are more easily mineralized, as evidenced by Fontana et al. (2010).
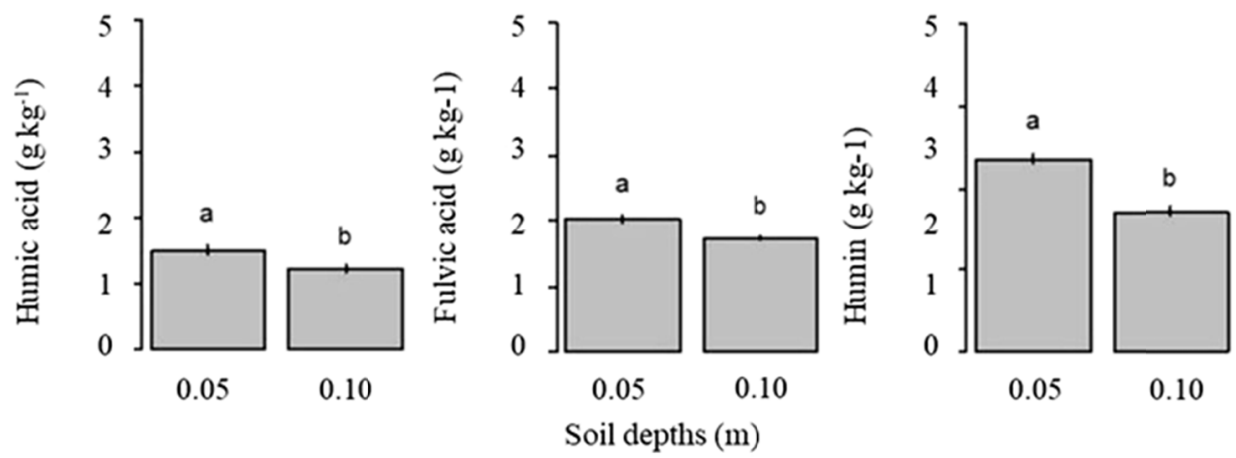

Figure 5. Averages of humic acid, fulvic acid and humin between the soil depths from 0 to 0.05 and 0.05 to 0.10 $\mathrm{m}$, in Uberaba, $\mathrm{MG}$

\section{Discussion}

In similar studies evaluating dry biomass production in nearby areas, it was observed that biomass production depends on the season that the crop is cultivated. In the year 2010, Torres et al. (2013) conducted a study with cover crops during March to June (beginning of Winter) and observed that DB production reached $12.2 \mathrm{Mg} \mathrm{ha}^{-1}$ for millet and $10.5 \mathrm{Mg} \mathrm{ha}^{-1}$ for sunn hemp, higher than what was observed in this study.

In December 2012 (summer), Torres et al. (2015) observed that brachiaria, pearl millet and sunn hemp, in the same area, produced $6.5,8.6$ and $4.6 \mathrm{Mg} \mathrm{ha}^{-1}$ of $\mathrm{DB}$, respectively. These values are equivalent to those found by millet, and $180 \%$ and $130 \%$ lower for brachiaria and sunn hemp, when compared to the results obtained in this study. Cultivating millet and crotalaria between the months of October to January of the years 2014, 2015 and 2016, Leal Junior (2018), found DB of 11.1, 10.3 and $9.6 \mathrm{Mg} \mathrm{ha}^{-1}$ for millet, and 3.4, 15.5 and $10.2 \mathrm{Mg} \mathrm{ha}^{-1}$ for sunn hemp, respectively, which were higher values than those observed in this study, except for sunn hemp in 2014.

In the above-mentioned studies conducted in 2012, 2014, 2015 and 2016, and in this study, the first month of crop development presented similar temperature and precipitation (above $250 \mathrm{~mm}$ ), indicating that the DB can greatly vary among years. This variation in DB production can be an influence of soil fertility at the time of cover crop sowing, since they were sown without any fertilization, exactly to take advantage of the residual fertilization left by the preceding crop, which was different due to the rotation carried out in the areas.

According to Giacomini et al. (2003), when Fabaceae and Poaceae seeds are mixtured it is expected that the production of fresh biomass is greater than that obtained by the same plants in monoculture. The authors attributed this biomass increase in mixed cover crops to the high biological nitrogen fixation performed by the Fabaceae species, which provides great nitrogen availability to the soil, favoring the development of the Poaceae species. This increased biomass was observed in this study.

Cover crops mixtures tend to have a greater capacity to absorb more water and nutrients when compared to monoculture, because their root systems explore greater soil volumes and grow quicker than in monoculture. This situation was observed by Bettiol et al. (2015), who demonstrated that where sunn hemp is sown in mixture, the other cover crop presents greater biomass production than in monoculture.

These results demonstrate the good adaptation of these cover crops in monoculture or in mixtures to the edaphoclimatic conditions of the Cerrado biome. However, when brachiaria, millet and sunn hemp are sown at the beginning of the rainy period there are great biomass productions, within the range of 6 to 13,7 to 12 and 4 to $9 \mathrm{Mg} \mathrm{ha}^{-1}$, respectively (Chioderoli et al., 2012; Assis et al., 2016; Torres et al., 2015).

It was expected that the highest rates of decomposition occurred in sunn hemp-Fabaceae species have low $\mathrm{C} / \mathrm{N}$ ratio when compared to Poaceae species - as evidenced in other studies conducted in Cerrado (Pacheco et al., 2011; Torres et al., 2015; Collier et al., 2018). However, this did not occur in this study, since the highest 
decomposition rate occurred in the monoculture brachiaria, then by crotalaria, $\mathrm{M}+\mathrm{C}$ and $\mathrm{B}+\mathrm{C}$, which were those that have the lowest remaining biomass on the soil surface after 120 days.

In their studies, Assis et al. (2016) and Torres et al. (2017) observed similar results when using brachiaria, since the rate of decomposition of the brachiaria residues were accelerated when compared to crotalaria and millet, suggesting that it is not only the $\mathrm{C} / \mathrm{N}$ ratio of plant residues to decisively affect the process of plant residue decomposition. The $\mathrm{C} / \mathrm{N}$ that these plants feature in monoculture, when compared with cover crop mixtures, may present middle or higher ratios of decomposition, as evidenced in other studies carried out in the same region (Torres et al., 2013; Assis et al., 2016; Pacheco et al., 2013).

This great rate of decomposition of the brachiaria residues can be justified by the low temperature variation and elevated humidity conditions that occurred during this period of the year, in addition to the daily irrigation for vegetable production, which accelerates the decomposition process, as evidenced by Torres et al. (2015), Assis et al. (2016), Pacheco et al. (2017), and Collier et al. (2018).

Some other studies evaluating the decomposition of residues of millet, sunn hemp and brachiaria in natural conditions (no artificial irrigation) showed that the greatest rates of decomposition always occur on Fabaceae, and minor in Poaceae (Carvalho et al., 2011; Assis et al. 2016; Torres et al., 2015, 2017). These authors also observed that the rates are directly influenced by soil moisture because the decomposition increases in parallel to the increase of water availability that occurs in the rainy period and decrease to minimum values in the dry period (Torres et al., 2008; Pacheco et al., 2017).

In natural conditions (no artificial irrigation), a similar study evaluating the biomass production and mineralization of cover crops residues in NTS, found greater $\mathrm{T}^{1} / 2$ life for millet (131 days), sunn hemp (98 days) and brachiaria (56 days), which were 463,421 and $220 \%$ superior to those found in this study, respectively (Torres et al., 2008). In the harvest of 2008/09 and 2009/10, Pacheco et al. (2013) observed T1/2 life of 42 (165\%) and $111(435 \%)$ days for brachiaria, $63(223 \%)$ and 108 (382\%) days for millet, and $44(113 \%)$ and $130(334 \%)$ days for brachiaria + pigeonpea, respectively. Collier et al. (2018) observed $\mathrm{T}^{1} \frac{1}{2}$ life of 57 (245\%) days for sunn hemp when it was cultivated for 170 days. These results prove that the residue decomposition from the cover crops evaluated are decreased and present great $\mathrm{T}^{1 / 2}$ life on soil, when compared to the results observed in the irrigated area of this study.

Even in the conditions of stable temperatures and great humidity of the irrigated area, the mixtures $\mathrm{M}+\mathrm{S}$ and $\mathrm{B}$ $+\mathrm{S}$ (Fabaceae + Poaceae) presented a $\mathrm{T}^{1 / 2} \mathrm{l}$ life of 28.6 and 30.4 days, respectively, values that are significantly lower when compared to B + M, 38.9 days, composed by mixing Poaceae species, which are plants that have great $\mathrm{C} / \mathrm{N}$ ratio.

Pacheco et al. (2011) evaluated the decomposition rate of plant residues from mixtures of Fabaceae and Poaceae in the dry and rainy seasons, and observed $\mathrm{T}^{1} / 2$ life of 44 and 130 days for brachiaria + pigeonpea, respectively, while Rossi et al. (2013) evaluating brachiaria + soybean and sorghum + soybean, observed 99 and 385, and 115 and 495 days for the same seasons. The authors explained that the conditions of high precipitation favored the activity of soil microorganisms, accelerating the process of residue decomposition.

According to Giacomini et al. (2003), the mixture of Fabaceae and Poaceae in the same area produces residues with intermediate $\mathrm{C} / \mathrm{N}$ ratio, when compared with monocultures, and decelerate the decomposition process. This situation was also proven by Torres et al. (2013), Assis et al. (2016) and Pacheco et al. (2013). Bettiol et al. (2015) and Siqueira Neto et al. (2009) observed in their studies, that in cover crop mixtures including sunn hemp there is an increase in the biomass production, perhaps by the extra nitrogen supplied through the biological nitrogen fixation, which favors the development of the Poaceae species.

The evaluation of cover crops under different management systems indicated that Poaceae species as millet also assists in deep soil incorporation of carbon, which is related to the great development of the adventitious root system (Pereira et al., 2010). The low $\mathrm{C} / \mathrm{N}$ ratio also reduces the decomposition rate and contributes to the preservation of the soil organic matter.

According to Anghinoni (2007), in the first 5 years of NTS the soil still presents low levels of TOC, low accumulation of plant residue and low microbial activity during the restoration process, even so, the great values of TOC were observed in the most superficial soil layers. Pereira et al. (2010) studying different cover crops and their influence on the levels of TOC in a dystrophic red Oxisol, showed great values of TOC in the most superficial soil layers, similarly to what was observed in this study.

According to Lal (2006), the fixation of carbon in soil is a natural process that involves the transferring of atmospheric carbon to the soil, via biological and chemical transformations until the litter humification process is 
completed. Only 5 to $15 \%$ of the plant residues deposited on soil surface becomes humified matter, and this process mainly depends on the quantity and quality of the material deposited and on the agricultural management applied. Ruthner and Sevegnani (2012) emphasize that great plant residue accumulation on soil surface was due to the low rate of residue decomposition, which provides greater protection to the soil and retention of carbon in the SOM over time.

Evaluations of the stock of carbon (EstC) done by Pereira et al. (2010) in different management systems indicated that the use of millet produced great values of $\mathrm{EstC}$ in the 0 to $0.2 \mathrm{~m}$ soil layer, when compared to other cover crops such as sunn hemp and spontaneous vegetation. In the same study, it was observed that the use of millet assists in the incorporation of carbon in deep soil layers.

According to Lal (2006), the increase in TOC and in the EstC in soil occurs slowly, via biomass deposited on the soil surface and root degradation. Denef et al. (2008) further highlighted the great increase of TOC in areas managed with irrigation, resulting in greater deposition of plant residues on soil surface altering the coefficients of SOM. Analyzing the fertility and TOC in a Cerrado Oxisol under pasture, Loss et al. (2013), observed that in irrigated areas the levels of TOC were greater, and explaining this as a consequence of the great inflow of aboveground biomass and roots into the soil, and that this increase is more noticeable in the labile fractions of SOM.

In the soil depth of 0.05 to $0.1 \mathrm{~m}$, the biggest QSOM occurred in areas with $\mathrm{M}+\mathrm{S}\left(23.77 \mathrm{Mg} \mathrm{ha}^{-1}\right)$, brachiaria $\left(21.17 \mathrm{Mg} \mathrm{ha}^{-1}\right)$ and sunn hemp $\left(20.95 \mathrm{Mg} \mathrm{ha}^{-1}\right)$, which differed from the other treatments. This QSOM was greater where there was Poaceae in monoculture or in mixture, because these plants have a broad and deep root system, which promotes a great flow of organic matter in soil layers. According to Kuzyakov and Domanski (2000), when plant residues have great concentrations of lignin and aromatic compounds (higher $\mathrm{C} / \mathrm{N}$ ratio), the material presents a low decomposition rate, contributing to the maintenance of organic substances in the soil in the most superficial layers.

In a native forest the carbon content of humic substances of the SOM were quantified by Pessoa et al. (2012), and the authors found that in the $0 \mathrm{~s} 0.05 \mathrm{~m}$ soil layer, the SOM found were 4.7, 11 and $20.5 \mathrm{~g} \mathrm{~kg}^{-1}$ for the fractions of FA, HA and HUM, while in the 0.05 to $0.1 \mathrm{~m}$ soil layer, these levels were $4.1,8.9$ and $15.2 \mathrm{~g} \mathrm{~kg}^{-1}$, respectively. In general, the humin fraction showed the highest levels of carbon when compared to other fractions - humic and fulvic acids. In several studies evaluating the use and management of soils, it was also observed the predominance of carbon in the humin fraction in relation to the other fractions (Guareschi et al., 2012).

\section{Conclusions}

Brachiaria and sunn present the highest and the lowest volume of plant residues among the covers crops evaluated, respectively.

The cover crops in monoculture have higher decomposition rates and shorter half-life when compared to cover crops in mixtures under Cerrado edaphoclimatic conditions.

The content of total organic carbon and the coefficient of soil organic matter are significantly higher in the 0 to $0.05 \mathrm{~m}$ soil depth, and in the mixture millet + sunn hemp, when compared to other soil depths and cover crops treatments.

There is a predominance of humin in the soil profiles studied, and the highest concentrations of these fractions are found in the most superficial soil layer $(0$ to $0.05 \mathrm{~m})$, indicating that the accumulation of this insoluble fraction of the soil organic matter will increase over time under no-tillage systems.

\section{Acknowledgements}

To the Federal Institute of Triângulo Mineiro, Campus Uberaba, for the infrastructure provided; to the Foundation for Research Support of the State of Minas Gerais (FAPEMIG), to the Brazilian National Council for Scientific and Technological Development (CNPq), to the Coordination of Superior Level Staff Improvement (CAPES) by granting scholarships to the students, and to the Agrisus Foundation by financing part of the project.

\section{References}

Anghinoni, I. (2007). Fertilidade do solo e seu manejo no sistema plantio direto. In R. F. Novais, V. V. H. Alvarez, N. F. Barros, R. L. F. Fontes, R. B. Cantarutti, \& J. C. L. Neves (Eds.), Fertilidade do Solo (pp. 873-928). Soc Br Ci Sol., Viçosa. 
Assis, R. L., Boer, C. A., Pacheco, L. P., Braz, A. J. B. R., Costa K. A. P., \& Torres J. L. R. (2016). Produção e decomposição de biomassa de plantas de cobertura cultivadas na primavera. Energia na Agricultura, 31, 328-333. https://doi.org/10.17224/EnergAgric.2016v31n4p328-333

Benites, V. M., Madari, B., \& Machado, P. L. O. A. (2003). Extração e fracionamento quantitativo de substâncias húmicas do solo: Um procedimento simplificado de baixo custo. Embrapa, Rio de Janeiro

Bernoux, M., Cerri, C. C., Cerri, C. E. P., Siqueira Neto, M., Metay, A., Perrin, A. S., ... Milne, E. (2006). Cropping systems, carbon sequestration and erosion in Brazil: A review. Sustainable Agriculture, 1, 75-85. https://doi.org/10.1051/agro:2005055

Bettiol, J. V. T., Pedrinho, A., Merloti, L. F., Bossolani, J. W., \& Sá, M. E. (2015). Plantas de Cobertura utilizando Urochloa ruziziensis solteira e em consórcio com leguminosas e seus efeitos sobre a produtividade de sementes do feijoeiro. Uniciencias, 19, 13-10.

Branco, R. B. F., Blat, S. F., Gimenes, T. G. S., Nowaki, R. H. D., Araujo, H. S., \& Salles, F. A. (2017). Nitrogen fertilization of vegetables cultivated under no-tillage after cover crops. Horticultura Brasileira, 35, 103-110. https://doi.org/10.1590/s0102-053620170116

Carvalho, A. M., Souza, L. L. P., Guimarães Júnior, R., Alves, P. C. A. C., \& Vivaldi L. J. (2011). Cover plants with potential use for crop livestock integrated systems in the Cerrado region. Pesquisa Agropecuária Brasileira, 46, 1200-1205. https://doi.org/10.1590/S0100-204X2011001000012

Ceballos, G. A., Fabian, A. J., Silva, J. C. O., Torino, A. B., \& Bernardes G. F. (2018). Production and speed of decomposition of species of soil coverage in direct sowing system. Ciências Agrárias, 61, 1-6. https://doi.org/10.22491/rca.2018.2631

Chioderoli, C. A., Mello, L. K. M. M., Grigolli, P. J., Furlani, C. E. A., Silva, J. O. R., \& Cesarin, A. L. (2012). Atributos físicos do solo e produtividade de soja em sistema de consórcio milho e braquiária. Revista Brasileira de Engenharia Agrícola e Ambiental, 16, 37-43. https://doi.org/10.1590/S1415-436620120001 00005

Collier, L. S., Arruda, E. M., Campos, L. F. C., \& Nunes, J. N. V. (2018). Soil chemical attributes and corn productivity grown on legume stubble in agroforestry systems. Caatinga, 31, 279-289. https://doi.org/ 10.1590/1983-21252018v31n203rc

Denef, K., Stewart, C. E., Brenner, J., \& Paustian, K., (2008). Does long-term center-pivot irrigation increase soil carbon stocks in semi-arid agro-ecosystems? Geoderma, 145, 121-129. https://doi.org/10.1016/ j.geoderma.2008.03.002

Fontana, A., Brito, R. J., Pereira, M. G., Loss, A., \& Benites, V. M. (2010). Caracterização de susbtâncias húmicas da camada superficial do solo sob diferentes coberturas vegetais. Magistra, 22, 49-56.

Giacomini, S. J., Aita, C., Vendruscolo, E. R. R. O, Cubilla, M., Nicoloso, R. S., \& Fries, M. R. (2003). Matéria seca, relação $\mathrm{C} / \mathrm{N}$ e acúmulo de nitrogênio, fósforo e potássio em misturas de plantas de cobertura do solo. Revista Brasileira de Ciência do Solo, 27, 325-334. https://doi.org/10.1590/S0100-06832003000200012

Guareschi, R. F., Pereira, M. G., \& Perin, A. (2012). Deposição de resíduos vegetais, matéria orgânica leve, estoques de carbono e nitrogênio e fósforo remanescente sob diferentes sistemas de manejo no Cerrado goiano. Revista Brasileira de Ciência do Solo, 36, 909-920. https://doi.org/10.1590/S0100-06832012000 300021

INMet (Instituto Nacional de Meteorologia). (2018). Informações sobre as condições climáticas do município de Uberaba-MG. Retrieved from http://www. inmet.gov.br

IPCC (Intergovernmental Panel on Climate Change). (2003). Good practice guidance for land use-Land-use change and forestry. IGES, Hayama.

Köppen, W. (1936). Das geographische system der klimatologie. Berlin, Gebruder Borntrager.

Kuzyakov, Y., \& Domanski, G. (2000). Carbon input by plants into the soil. Journal of Plant Nutrition and Soil Science, 163, 421-431. https://doi.org/10.1002/1522-2624(200008)163:4\%3C421::AID-JPLN421\%3E3.0. $\mathrm{CO} ; 2-\mathrm{R}$

Lal, R. (2006). Soil carbon sequestration in Latin America. In R. Lal, C. C. Cerri, M. Bernoux, J. Etchevers, \& E. Cerri (Eds.), Carbon sequestration in soil of Latin America (pp. 41-47). New York, Haworth. 
Leal Júnior, A. L. B. (2018). Plantio direto de milho safrinha em áreas descompactadas mecânica e biologicamente. Instituto Federal do Triângulo Mineiro (IFTM), Uberaba.

Loss, A., Pereira, M. G., Perin, A., Beutler, S. J., \& Anjos, L. H. C. (2013). Oxidizable carbon and humic substances in rotation systems with brachiaria/livestock and pearl millet/no livestock in the Brazilian Cerrado. Spanish Journal of Agricultural Research, 11, 217-231. https://doi.org/10.5424/sjar/2013111-3416

Motter, P., \& Goelzer, H. A. (2015). Plantio direto: A tecnologia que revolucionou a agricultura brasileira. Parque Itaipu, Foz do Iguaçu.

Pacheco, L. P., Barbosa, J. M., Leandro, W. M., Machado, P. L. O. A., Assis, R. L., Madari, B. E., \& Petter, F. A. (2013). Ciclagem de nutrientes por plantas de cobertura e produtividade de soja e arroz em plantio direto. Pesquisa Agropecuária Brasileira, 48, 1228-1236. https://doi.org/10.1590/S0100-204X2013000900006

Pacheco, L. P., Fonseca, W. L., Menezes, C. C. E., Leandro, W. M., Assis, R. L., \& Petter, F. A. (2018). Phytomass production and micronutrient cycling by cover crops in the Brazilian cerrado of Goiás. Comunicata Scientiae, 9, 12-18. https://doi.org/10.14295/cs.v9i1.1094

Pacheco, L. P., Leandro, W. M., Machado, P. L. O. A., Assis, R. L., Cobucci, T., Madari, B. E., \& Petter, F. A. (2011). Produção de fitomassa e acúmulo e liberação de nutrientes por plantas de cobertura na safrinha. Pesquisa Agropecuária Brasileira, 46, 17-25. https://doi.org/10.1590/S0100-204X2011000100003

Pacheco, L. P., Miguel, A. S. D. C. S., Silva, R. G., Souza, E. D., Petter, F. A., \& Kappes, C. (2017). Biomassa yield in production systems of soybean sown in succession to annual crops and cover crops. Pesquisa Agropecuária Brasileira, 52, 582-591. https://doi.org/10.1590/s0100-204×2017000800003

Paul, E. A., \& Clark, F. E. (1996). Dynamics of residue decomposition and soil organic matter turnover. In E. A. Paul, \& F. E. Clark (Eds.), Soil microbiology and biochemistry (pp. 158-179), Academic, San Diego.

Pereira, M. G., Loss, A., Beutler, S. J., \& Torres, J. L. R., (2010). Carbono, matéria orgânica leve e fósforo remanescente em áreas de Cerrado sob plantio direto. Pesquisa Agropecuária Brasileira, 45(5), 508-514. https://doi.org/10.1590/S0100-204X2010000500010

Pessoa, P. M. A., Duda, G. P., Barros, R. B., Freire, M. B. G. S., Nascimento, C. W. A., \& Correa, M. M. (2012). Frações de carbono orgânico de um Latossolo Húmico sob diferentes usos no agreste brasileiro. Revista Brasileira de Ciência do Solo, 36, 97-104. https://doi.org/10.1590/S0100-06832012000100011

Rossi, C. Q., Pereira, M. G., Giacomo, S. G., Betta, M., \& Polidoro, J. C. (2013). Decomposição e liberação de nutrientes da palhada de braquiária, sorgo e soja em áreas de plantio direto no Cerrado goiano. Semina, 34, 1523-1534. https://doi.org/10.5433/1679-0359.2013v34n4p1523

Rossi, C. Q., Pereira, M. G., Giacomo, S. G., Betta, M., \& Polidoro, J. C. (2011). Frações húmicas da matéria orgânica do solo cultivado com soja sobre palhada de braquiária e sorgo. Bragantia, 70, 622-630. https://doi.org/10.1590/S0006-87052011000300018

Ruthner, R. R., \& Sevegnani, L. (2012). Teores de carbono armazenado no solo e na serapilheira sob floresta ombrófila densa de terras baixas e submontanha do Vale do Itajaí, SC. Revista Científica Semana Acadêmica, 8(1), 1-26.

Santos, H. G. dos, Jacomine, P. K. T., Anjos, L. H. C. dos, Oliveira, V. A. de, Lumbreras, J. F., Coelho, M. R., ... Oliveira, J. B. de. (2013). Sistema brasileiro de classificação de solos (3rd ed.). Embrapa, Brasília.

Siqueira Neto, M., Venzke Filho, S. P., Piccolo, M. C., Cerri, C. E. P., \& Cerri C. C. (2009). Rotação de culturas no sistema plantio direto em Tibagi (PR). I-Sequestro de carbono no solo. Revista Brasileira de Ciência do Solo, 33, 1012-1022. https://doi.org/10.1590/S0100-06832009000400025

Teixeira, P. C., Donagemma, G. K., Fontana, A., \& Teixeira, W. G. (2017). Manual de Métodos de Análise de Solos (3rd ed.). Embrapa, Rio de Janeiro.

Thomas, R. J., \& Asakawa, N. M. (1993). Decomposition of leaf litter from tropical forage grasses and legumes. Soil Biology \& Biochemistry, 25, 1351-1361. https://doi.org/10.1016/0038-0717(93)90050-L

Torres, J. L. R., Araújo, A. S., Barreto, A. C., Silva Neto, O. F., Silva, V. R., \& Vieira, D. M. S. (2015). Desenvolvimento e produtividade de couve-flor e repolho influenciados por tipos de cobertura do solo. Horticultura Brasileira, 33, 510-514. https://doi.org/10.1590/S0102-053620150000400017

Torres, J. L. R., Gomes, F. R. C., Barreto, A. C., Tamburús, A. Y., Vieira, D. M. S., Souza, Z. M., \& Mazetto Júnior, J. C. (2017). Application of different cover crops and mineral fertilizer doses for no-till cultivation 
of broccoli, cauliflower and cabbage. Australian Journal of Crop Science, 11, 1339-1345. https://doi.org/ 10.21475/ajcs.17.11.10.pne645

Torres, J. L. R., Pereira, M. G., \& Fabian, A. J. (2008). Produção de fitomassa por plantas de cobertura e mineralização de seus resíduos em plantio direto. Pesquisa Agropecuária Brasileira, 43, 421-428. https://doi.org/10.1590/S0100-204X2008000300018

Torres, J. L. R., Santana, M. J., Pizolato Neto, A., Pereira, M. G., \& Vieira, D. M. S. (2013). Produtividade de feijão sobre lâminas de irrigação e coberturas de solo. Bioscience Journaul, 29, 833-841.

Yeomans, J. C., \& Bremner, J. M. (1988). A rapid and precise method for routine determination of carbon in soil. Communications in Soil Science and Plant Analysis, 19, 1467-1476. https://doi.org/10.1080/001036288 09368027

Zotarelli, L., Zatorre, N. P., Boddey, R. M., Jantalia, C. P., Urquiaga, S., Franchini, J. C., \& Alves, B. R. (2012). Influence of no-tillage and frequency of a green manure legume in crop rotations for balancing $\mathrm{N}$ outputs and preserving soil organic C stocks. Field Crops Research, 132, 185-195. https://doi.org/10.1016/j.fcr. 2011.12.013

\section{Copyrights}

Copyright for this article is retained by the author(s), with first publication rights granted to the journal.

This is an open-access article distributed under the terms and conditions of the Creative Commons Attribution license (http://creativecommons.org/licenses/by/4.0/). 